Florian Wichern - Ingo Lobe - Wulf Amelung •

Torsten Müller • Rainer Georg Joergensen •

Andreas Buerkert

\title{
Changes in amino acid enantiomers and microbial performance in soils from a subtropical mountain oasis in Oman abandoned for different periods
}

Received: 31 March 2003 / Accepted: 7 January 2004 / Published online: 28 February 2004

(C) Springer-Verlag 2004

\begin{abstract}
An important feature of maintaining the agricultural stability in millennia-old mountain oases of northern Oman is the temporary abandonment of terraces. To analyse the effects of a fallow period on soil microbial performance, i.e. microbial activity and microbial biomass, samples of eight terrace soils abandoned for different periods were collected in situ, assigned to four fallow age classes and incubated for 30 days in the laboratory after rewetting. The younger fallow age classes of 1 and 5 years were based on the records of the farmers' recollections, the two older fallow age classes of 10-20 and 25-60 years according to the increase in the $\mathrm{D}-$-to- $\mathrm{L}$ ratio of valine and leucine enantiomers. The increase in these two ratios was in agreement with that of the D -to- $\mathrm{L}$ ratio of lysine. The strongest relationship was observed between the increase in the $\mathrm{D}$-to- $\mathrm{L}$ ratio of lysine and the decrease in soil microbial biomass C. However, the most stringent coherence between the increase in fallow age and soil properties was revealed by the decreases in cumulative respiration and net $\mathrm{N}$ mineralisation rates with decreasing availability of substrate to soil microorganisms. During the 30-day incubation following rewetting, relative changes in microbial activity (respiration and net $\mathrm{N}$ mineralisation) and microbial biomass $(\mathrm{C}$ and $\mathrm{N})$
\end{abstract}

F. Wichern · T. Müller · R. G. Joergensen $(\bullet)$

Department of Soil Biology and Plant Nutrition,

University of Kassel,

Nordbahnhofstrasse 1a, 37213 Witzenhausen, Germany

e-mail: joerge@wiz.uni-kassel.de

Tel.: +49-5542-981591

Fax: +49-5542-981596

I. Lobe $\cdot$ W. Amelung

Institute of Ecology, Department of Soil Science,

Technical University of Berlin,

Salzufer 11-12, 10587 Berlin, Germany

A. Buerkert

Institute of Crop Science,

University of Kassel,

Steinstrasse 19, 37213 Witzenhausen, Germany indices were similar in the eight terrace soils on a fallow age-class-specific level, indicating that the same basic processes occurred in all of the sandy terrace soils investigated.

Keywords D -to- $\mathrm{L}$ ratio $\cdot$ Fallow $\cdot$ Rewetting $\cdot$ Microbial biomass $\cdot$ Microbial activities

\section{Introduction}

Under hot arid conditions with only scarce, but heavy rainfall events, where water is the most limiting factor for crop growth, agriculture often developed as complex oasis systems near springs, wells or rivers (Mainguet 1998). The millennia-old mountain oases in the north of Oman are typical examples of this kind of agriculture, where organic material and nutrients have been accumulated on small plots, raising considerably the fertility of the native soil stratum that was derived from wadi sediments (Nagieb et al. 2004). In arid regions, the organic matter content plays an important role in water retention and cation exchange capacity (CEC), especially on sandy soils (Craswell and Lefroy 2001). In times of low water availability and higher water consumption by the plants, such as in the hot season or in dry years, fields are often temporarily abandoned until higher water availability or a decrease in the evapotranspirational demand allow their recultivation (Mainguet 1998). Fallows under these conditions comprise usually more or less bare soils with scarce or no vegetation. No regular input of organic matter and water takes place during the times of abandonment. Consequently, a major threat to the soil fertility of these abandoned fields is erosion by occasionally occurring strong winds and by rare but heavy rainfall (Norman et al. 1998).

Drying and rewetting cycles are major stress events for soil microorganisms under hot and arid conditions (West et al. 1989; Fierer and Schimel 2002). Even after only a short duration, these might lead to a serious decline in 
microbial biomass, especially in combination with the reduced $\mathrm{C}$ input following the scanty growth of rain-fed plants. At present, it is completely unknown to what extent soil microorganisms are able to recover from longterm periods of desiccation. For this reason, the objective of this study was to assess the effects of length of fallow period on soil microbial biomass and activity indices, such as respiration and net $\mathrm{N}$ mineralisation after rewetting. However, to achieve this objective, each fallow's age according to local farmers needs to be verified by an independent method, e.g. the changes in the $\mathrm{D}$-to- $\mathrm{L}$ ratio of certain amino acid enantiomers (Amelung 2003). As living organisms on earth almost exclusively use L -amino acids, the detection of $\mathrm{D}$-amino acids in the environment can in part be used to monitor the aging of soil organic matter (Mahaney and Rutter 1989; Kimber et al. 1994; Miller et al. 1997).

This study was part of a larger project focussing on the sustainability of oasis systems, especially with respect to the question of how the current levels of agricultural inputs affect the $\mathrm{C}$ and $\mathrm{N}$ turnover under regular irrigation and high ambient temperatures (Nagieb et al. 2004; Wichern et al. 2004a).

\section{Materials and methods}

Study site

The investigation took place at the oasis of Maqta $\left(22.83^{\circ} \mathrm{N}\right.$, $59.00^{\circ} \mathrm{E}, 1050 \mathrm{~m}$ above sea level) in the north of the Sultanate of Oman. This oasis is located in the arid environment of the Hajar Mountains with a long-term total annual rainfall of approximately $100 \mathrm{~mm}$. Two distinct seasons exist in this area: a very hot summer with temperatures up to $45^{\circ} \mathrm{C}$ from May to September and a colder season with temperatures as low as $5^{\circ} \mathrm{C}$ from October to April. In Maqta, the different terrace systems are scattered over an area of approximately $2.5 \mathrm{~km}^{2}$. Most of the cultivated plots on 16 terrace systems are palm groves (2.9 ha) and only a 0.4-ha area is cultivated with annual crops, mainly landraces of wheat (Triticum aestivum L. and Triticum durum L.). During the hot season, the area cultivated with annual crops decreases to almost zero. The water is supplied to the plants by surface irrigation from 22 small springs. Typically, individually irrigated plots (jalba) of $1-5 \mathrm{~m}^{2}$ are flooded periodically according to the requirements of the respective crops.

\section{Soil sampling and analysis}

Soil samples were taken in March 2002 at 0-10 cm depth from eight different terraces forming four pairs of fallow age classes. According to the farmers interviewed, these terraces have been abandoned for estimated periods of 1 year, 5 years, 15-50 (25-65) years and $>50$ (10-20) years. The fallow age of the two older age classes were corrected (in brackets) on the basis of the increase in the D -to- L ratio of valine and leucine enantiomers, independently proven by the increase in the D -to- L ratio of lysine. Air-dried samples were sieved $(<2 \mathrm{~mm})$ and transferred to Germany within 3-4 weeks in polyethylene bags. The clay content was determined by a pipette method after pre-treatment with $\mathrm{H}_{2} \mathrm{O}_{2}$, Na-citrate and $\mathrm{Na}_{2} \mathrm{~S}_{2} \mathrm{O}_{4}$ to remove organic matter and iron oxides (Gee and Bauder 1986). The CEC was measured in unbuffered $0.1 \mathrm{M} \mathrm{BaCl}_{2}$ solution (Schlichting et al. 1995). Exchangeable cations ( $\mathrm{Na}, \mathrm{K}, \mathrm{Mg}, \mathrm{Ca}$ ) were measured by atomic absorption spectrometry (Varian AA775). Subsamples of dried soil material were homogenised in a ball mill. Thereafter, total $\mathrm{C}$ and total $\mathrm{N}$ were determined using gas chromatography after combustion at $1200^{\circ} \mathrm{C}$ using a Carlo Erba ANA 1400 analyser. The carbonate content was estimated manometrically. Soil organic C was calculated as the difference between total $\mathrm{C}$ minus carbonate $\mathrm{C}$.

D -to- $\mathrm{L}$ ratios of amino acids

As soils may contain a variety of amino acids in free forms (Nagata et al. 1998), we removed all free amino acids by extracting the samples overnight $(8-12 \mathrm{~h}$ ) with cold $1 \mathrm{M} \mathrm{HCl}$ (Kvenvolden and Peterson 1970). The remaining, bound amino acids were then liberated by hydrolysis of $0.4-$ to 0.8 -g samples (corresponding to $0.2-0.4 \mathrm{mg} \mathrm{N})$ in $6 \mathrm{M} \mathrm{HCl}\left(12 \mathrm{~h}, 105^{\circ} \mathrm{C}\right)$. After filtration through a glass fibre filter (GF 6; Schleicher \& Schuell, Dassel, Germany), the purification procedure was carried out as described by Amelung and Zhang (2001) using a preparation column with Dowex $50 \mathrm{~W} \times 8$ cation exchange resin rinsed with $0.1 \mathrm{M}$ oxalic acid $(\mathrm{pH} 1.7$ with $\mathrm{NH}_{4} \mathrm{OH}$ ) to remove interfering metals. The amino acids were transferred into volatile derivatives as $\mathrm{N}$-pentafluoropropionic anhydride amino acid isopropyl esters. The separation of the amino acid enantiomers was carried out on a Hewlett-Packard 6890 gas chromatograph. It was equipped with an HP 2371 mass-sensitive detector (Agilent Technologies, Palo Alto, Calif.), operated in the selective ion-monitoring mode. Helium was used as carrier gas. A 30-m capillary column coated with Chirasil- L -Val was used to separate amino acid derivatives with a split ratio of 60-to-1. Quantification was performed relative to the internal standard $\mathrm{L}$-norvaline, added to the samples after hydrolysis. D -Methionine was added as a second internal standard to determine the recovery of L -norvaline; it averaged $104 \pm 7 \%$ of the initial spike amount. All analyses were run in duplicate.

Incubation experiment

Soil samples of $300 \mathrm{~g}$ (on an oven-dry basis) were incubated in triplicate for 30 days in 1-1 stoppered glass jars at $23^{\circ} \mathrm{C}$ in the dark after rewetting to $50 \%$ water holding capacity. Soil respiration was continuously measured as $\mathrm{O}_{2}$ consumption using an Aqualytic (Darmstadt, Germany) tension-recording device (Robertz et al. 1999). The $\mathrm{CO}_{2}$ produced was absorbed in $40 \% \mathrm{KOH}$. For better comparison with published data, the $\mathrm{CO}_{2}$ production was then calculated from the $\mathrm{O}_{2}$ consumption, assuming a respiratory quotient of 1 . However, it should be noted that this assumption is true for the decomposition of glucose-like substrates only and might be wrong for the soil organic matter in true soil samples like those of this study (Dilly 2001). Moist soil of approximately $30 \mathrm{~g}$ (on an oven-dry basis) was removed from each jar after 3, 8, 13, 17, 22 and 30 days for measuring net $\mathrm{N}$ mineralised $\left(\mathrm{NO}_{3}{ }^{-}\right.$and $\left.\mathrm{NH}_{4}{ }^{+}\right)$, microbial biomass $\mathrm{C}$ and biomass $\mathrm{N}$.

\section{Microbial biomass and $\mathrm{K}_{2} \mathrm{SO}_{4}$-extractable components}

Microbial biomass $\mathrm{C}$ and biomass $\mathrm{N}$ in the 30 -g samples removed from the 1-1 incubation jars were estimated by fumigation-extraction (Brookes et al. 1985; Vance et al. 1987). One portion of $10 \mathrm{~g}$ (on an oven-dry basis) moist soil was fumigated for $24 \mathrm{~h}$ at $25^{\circ} \mathrm{C}$ with ethanol-free $\mathrm{CHCl}_{3}$. Following fumigant removal, the sample was extracted with $40 \mathrm{ml}$ of $0.5 \mathrm{M} \mathrm{K}_{2} \mathrm{SO}_{4}$ by $30 \mathrm{~min}$ of horizontal shaking at 200 r.p.m. and filtered through a folded filter paper (595 $1 / 2$, Schleicher \& Schuell). The non-fumigated 10 -g portion was extracted similarly at the time when fumigation commenced. Organic $\mathrm{C}$ in the extracts was measured as $\mathrm{CO}_{2}$ by infrared absorption after combustion at $850^{\circ} \mathrm{C}$ using a Dimatoc 100 automatic analyser (Dimatec, Essen, Germany). Microbial biomass $\mathrm{C}$ was calculated as follows: microbial biomass $\mathrm{C}=E_{\mathrm{C}} / k_{\mathrm{EC}}$, where $E_{\mathrm{C}}=($ organic $\mathrm{C}$ extracted from fumigated soils $)-($ organic $\mathrm{C}$ extract ed from non-fumigated soils) and $k_{\mathrm{EC}}=0.45$ (Wu et al. 1990). Total $\mathrm{N}$ in the extracts was measured as $\mathrm{NO}_{2}{ }^{*}$ after combustion at $850^{\circ} \mathrm{C}$ using a Dima-N chemoluminescence detector (Dimatec). Microbial 
biomass $\mathrm{N}$ was calculated as follows: microbial biomass $\mathrm{N}=E_{\mathrm{N}} /$ $k_{\mathrm{EC}}$, where $E_{\mathrm{N}}=$ (total $\mathrm{N}$ extracted from fumigated soils)-(total $\mathrm{N}$ extracted from non-fumigated soils) and $k_{\mathrm{EN}}=0.54$ (Brookes et al. 1985; Joergensen and Mueller 1996). In the $0.5 \mathrm{M} \mathrm{K}_{2} \mathrm{SO}_{4}$ extracts of non-fumigated soil samples, $\mathrm{NO}_{3}-\mathrm{N}$ and $\mathrm{NH}_{4}-\mathrm{N}$ were additionally measured using segmented continuous flow analysis followed by spectrometric detection. Extractable organic $\mathrm{N}$ was calculated as the difference between extractable total and inorganic $\mathrm{N}$.

Statistics

The results presented in the tables are arithmetic means and expressed on an oven-dry basis (about $24 \mathrm{~h}$ at $105^{\circ} \mathrm{C}$ ). The significance of differences was tested by a two-way ANOVA using fallow age class $(1,5,10-20,25-60$ years) and terrace soil (two replicate terraces) as main factors and sampling date as repeated measures. This analysis and all other statistical evaluations such as non-linear and linear regression analyses were performed using StatView 5.0 (SAS)

\section{Results}

\section{Soil properties}

Sand contributed nearly three-quarters of the carbonatefree mineral substrate in three of the four fallow age classes, clay only $5 \%$ (Table 1 ). In the soils of the 5 -years fallow age class, the sand content was considerably lower and the clay content doubled in comparison to the other three age classes. The carbonate content varied between $12 \%$ and $26 \%$ (Table 1) and consisted of one-third $\mathrm{CaCO}_{3}$ and two-thirds $\mathrm{MgCO}_{3}$ (results not shown). The CEC ranged from 66 to $128 \mu \mathrm{mol}_{\mathrm{C}} \mathrm{g}^{-1}$ and was dominated by $\mathrm{Ca}$ and $\mathrm{Mg}$ (Table 1). CEC was strongly correlated with the soil organic $\mathrm{C}$ content $(r=0.95, n=8, P<0.001)$, which ranged from 6.0 in the soils of the 25- to 60-years fallow age class to $17.9 \mathrm{mg} \mathrm{C} \mathrm{g}^{-1}$ soil in the more clayey soils of the 5-years fallow age class. The total $\mathrm{N}$ content followed that accordingly with a soil-organic $\mathrm{C}$-to-total $\mathrm{N}$ ratio of around 11.7 .

The D -to- $\mathrm{L}$ ratio of seven amino acid enantiomers varied between $0.9 \%$ (proline) and $71.6 \%$ (aspartic acid) (Table 2). It was consistently around or above $10 \%$ for glutamic acid, aspartic acid, and alanine, and below $4 \%$ for valine, leucine, proline, and lysine. The highest $\mathrm{D}$-to$\mathrm{L}$ ratio was always found in the soils of the 25- to 60-years fallow age class, the lowest $\mathrm{D}$-to- $\mathrm{L}$ ratio was observed for three neutral amino acids (leucine, valine, and proline) in the 1-year fallow age class and for the other four amino acids (glutamic acid, aspartic acid, alanine, and lysine) in the 5-years fallow age class. The D -to- L ratio of lysine showed a significant linear decline with decreasing total $\mathrm{N}$ content (Fig. 1a).

The increase in the D -to- $\mathrm{L}$ ratio of valine and leucine in the four soils of fallow age class 1- and 5-years was used to estimate the fallow age of the other four soils by linear regression analysis. The increase in the D -to- L ratio of lysine revealed a strong correlation with the estimated fallow age (Fig. 2), as did the increase in the D -to- L ratio of the other four amino acids (proline, glutamic acid, aspartic acid, and alanine) (results not shown). As shown in Fig. 2, the four soils with a fallow period of $>5$ years were definitely assigned to a 10- to 20years and 25- to 60-years age class.

Table 1 Soil physical and chemical properties at $0-10 \mathrm{~cm}$ depth of abandoned terrace soils from four fallow age classes collected at the mountain oasis of Maqta, Oman. CEC Cation exchange

capacity, $C V_{T}$ mean $(n=4)$ coefficient of variation $(\mathrm{CV})$ between the terrace soils of a certain fallow age class $(n=2)$

\begin{tabular}{|c|c|c|c|c|c|c|c|c|c|c|c|}
\hline Fallow & Sand & Silt & Clay & Carbonate & CEC & $\mathrm{Na}$ & $\mathrm{K}$ & $\mathrm{Mg}$ & $\mathrm{Ca}$ & Soil organic $\mathrm{C}$ & Total $\mathrm{N}$ \\
\hline (years) & $(\%)$ & & & & $\overline{(\mu \mathrm{mo}}$ & $\mathrm{g}^{-1} \mathrm{soi}$ & & & & $\left(\mathrm{mg} \mathrm{g}^{-1}\right.$ soil) & \\
\hline 1 & 74 & 22 & 4 & 12 & 96 & 2.1 & 2.8 & 41 & 50 & 12.5 & 1.15 \\
\hline 5 & 48 & 42 & 10 & 26 & 128 & 1.2 & 9.4 & 41 & 77 & 17.9 & 1.47 \\
\hline $10-20$ & 70 & 25 & 5 & 15 & 97 & 1.0 & 2.6 & 29 & 64 & 12.4 & 1.15 \\
\hline $25-60$ & 75 & 20 & 5 & 17 & 66 & 1.2 & 3.2 & 19 & 43 & 6.0 & 0.48 \\
\hline $\mathrm{CV}_{\mathrm{T}}( \pm \%)$ & 10 & 20 & 7 & 23 & 11 & 31 & 43 & 18 & 23 & 9.4 & 14 \\
\hline
\end{tabular}

Table 2 D-to-L ratio (on a $\mu$ g basis) of seven amino acids (acidicglutamic acid and aspartic acid; neutral-valine, leucine, and proline; basic-lysine) in abandoned terrace soils from four fallow age classes collected at the mountain oasis of Maqta, Oman. $C V_{T}$ mean $(n=4)$ coefficient of variation $(\mathrm{CV})$ between the terrace soils of a certain fallow age class $(n=2), C V_{R}$ mean $(n=8) C V$ between the replicates $(n=2)$

\begin{tabular}{|c|c|c|c|c|c|c|c|}
\hline Fallow & Glutamic acid & Aspartic acid & Alanine & Valine & Leucine & Proline & Lysine \\
\hline (years) & $\mathrm{D} / \mathrm{L}(\%)$ & & & & & & \\
\hline 1 & 12.4 & 14.4 & 9.6 & 1.9 & 2.6 & 0.9 & 1.4 \\
\hline 5 & 12.1 & 12.2 & 9.2 & 2.0 & 2.8 & 0.9 & 1.3 \\
\hline $10-20$ & 12.6 & 17.9 & 9.5 & 2.2 & 3.1 & 1.1 & 1.9 \\
\hline $25-60$ & 18.8 & 71.6 & 15.7 & 3.2 & 3.7 & 1.3 & 2.4 \\
\hline $\mathrm{CV}_{\mathrm{T}}( \pm \%)$ & 10.4 & 30 & 10.0 & 11.1 & 8.9 & 9.6 & 10.7 \\
\hline $\mathrm{CV}_{\mathrm{R}}( \pm \%)$ & 4.2 & 12 & 4.2 & 2.5 & 2.0 & 6.4 & 3.0 \\
\hline
\end{tabular}



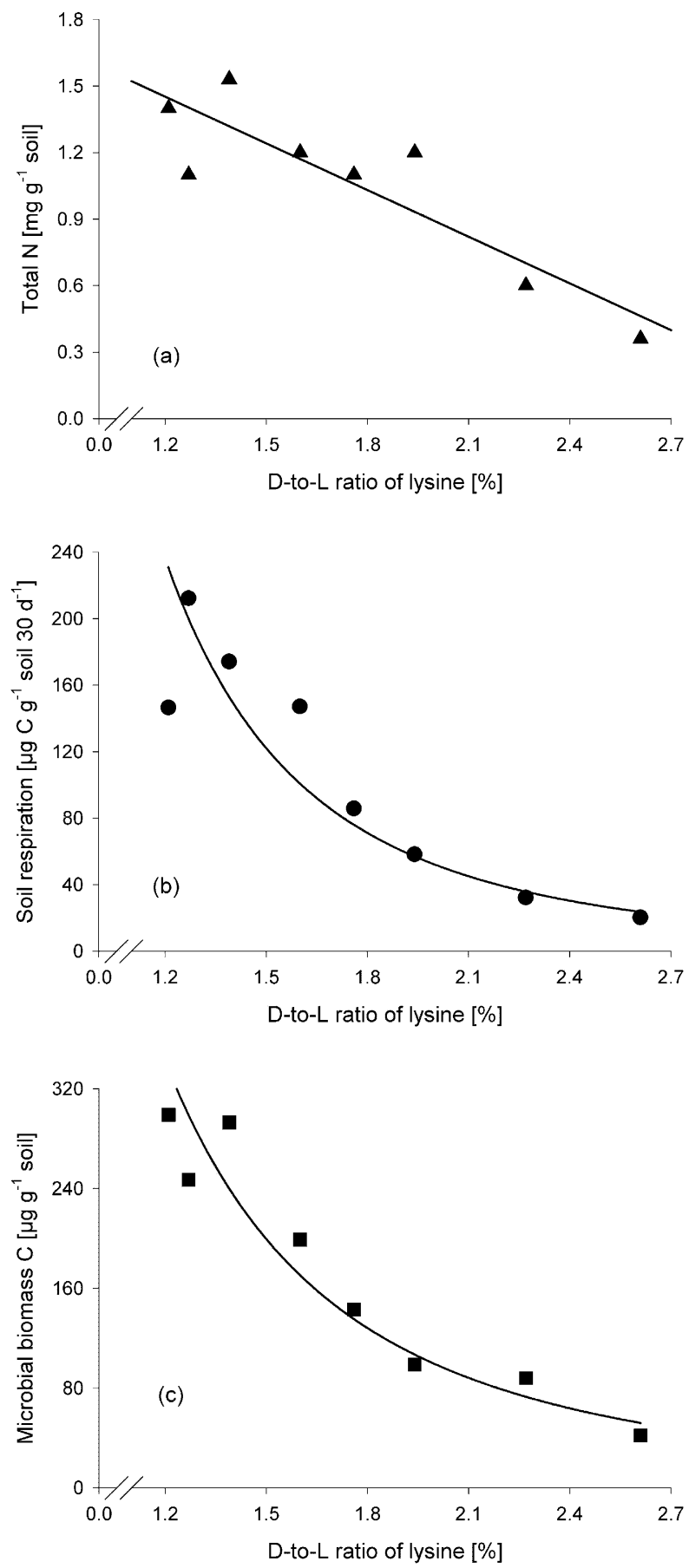

Fig. 1 a Linear relationship between the D -to- $\mathrm{L}$ ratio of lysine and total $\mathrm{N}$ content $[y=2.3-0.70 x, r=-0.89, P(x)=0.0034, n=8]$ in abandoned terrace soils collected at the mountain oasis of Maqta, Oman. b Non-linear relationship between the $\mathrm{D}$-to- $\mathrm{L}$ ratio of lysine and soil respiration $\left[y=406 x^{-2.96}, P(x)=0.0002, n=8\right]$. c Nonlinear relationship between the $\mathrm{D}$-to- $\mathrm{L}$ ratio of lysine and soil microbial biomass C $\left[y=534 x^{-2.43}, P(x)<0.0001, n=8\right]$

\section{Soil respiration}

The sum of $\mathrm{CO}_{2}-\mathrm{C}$ evolved over the 30-day incubation ranged from 26 to $180 \mu \mathrm{g} \mathrm{g}^{-1}$ soil corresponding to $0.4 \%$

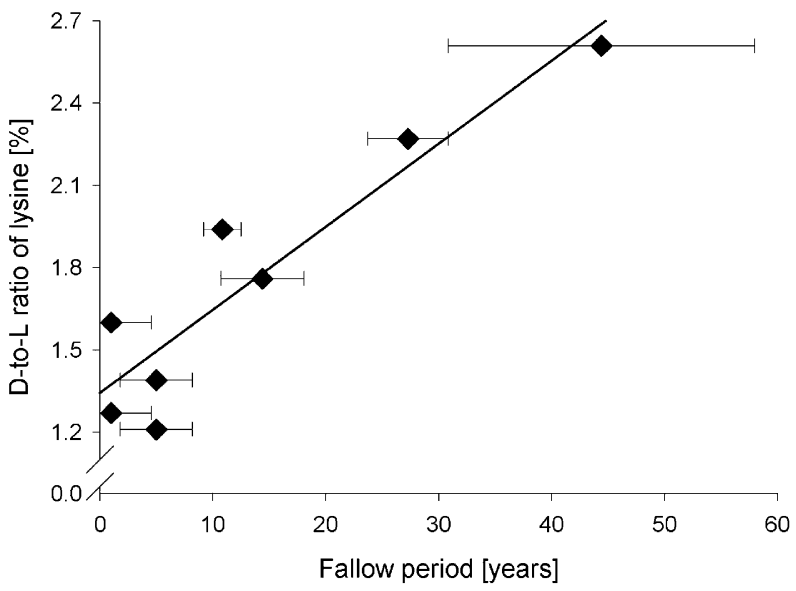

Fig. 2 Linear relationship between fallow period and the $\mathrm{D}$-to- L ratio of lysine $[y=1.3+0.033 x, r=0.93, P(x)=0.0009, n=8]$ in abandoned terrace soils collected at the mountain oasis of Maqta, Oman. The 1- and 5-years fallow age was estimated according to the farmers' recollections, the fallow age of the other four soils was estimated by the linear increase in the $\mathrm{D}$-to- $\mathrm{L}$ ratios of leucine and valine from fallow year 1 to fallow year 5. Error bars indicate the SEM ( $n=4$, soils of the 1 - and 5 -years fallow age class; $n=2$, all other soils)

and $1.4 \%$ of soil organic $\mathrm{C}$ (Table 3 ). The absolute respiration rate and the soil organic matter-specific respiration rate decreased consistently with increasing fallow age. The cumulative respiration rate showed a highly significant negative non-linear relationship with the D -to- $\mathrm{L}$ ratio of lysine (Fig. 1b). After rewetting, the changes in microbial respiration rates were similar at a fallow age class-specific level during the 30-day incubation (Fig. 3). The $\mathrm{CO}_{2}$ evolution rate decreased until day 17, especially in the two younger fallow age classes, remained more or less constant for the next 5 days, followed by a slight increase until day 30 in three of the four fallow age classes.

\section{Changes in $\mathrm{K}_{2} \mathrm{SO}_{4}$-extractable $\mathrm{N}$ and $\mathrm{C}$}

The sum of $0.5 \mathrm{M} \mathrm{K}_{2} \mathrm{SO}_{4}$-extractable inorganic $\mathrm{N}\left(\mathrm{NH}_{4}{ }^{+}-\right.$ $\mathrm{N}+\mathrm{NO}_{3}{ }^{-}-\mathrm{N}$ ) net mineralised over the 30-day incubation ranged from 1.4 to $9.6 \mu \mathrm{g} \mathrm{g}^{-1}$ soil, corresponding to 0.4 and $0.8 \%$ of total $\mathrm{N}$ (Table 3 ). As for the respiration rate, the absolute amount of net $\mathrm{N}$ mineralised and the soil organic matter-specific $\mathrm{N}$ mineralisation rate as \% total $\mathrm{N}$ both decreased consistently with increasing fallow age.

After rewetting, a first maximum of $0.5 \mathrm{M} \mathrm{K}_{2} \mathrm{SO}_{4}$ extractable inorganic $\mathrm{N}$ was observed at day 3 after rewetting (Fig. 4a). Until day 8, inorganic $\mathrm{N}$ decreased again, slightly in the soils of the 25- to 60-years fallow age class, but strongly, by nearly $50 \%$, in the 1 -year fallow age class. Thereafter, the content of extractable inorganic $\mathrm{N}$ increased until day 23 , reaching or exceeding the first maximum in the soils of all four fallow age classes, followed again by a slight decrease until day 30 . Extractable organic $\mathrm{N}$ components behaved exactly op- 
Table 3 Cumulative soil respiration ( $\mathrm{SCO}_{2}-\mathrm{C}$ ), net $\mathrm{N}$ mineralised $\left(\mathrm{NO}_{3}{ }^{-}-\mathrm{N}+\mathrm{NH}_{4}{ }^{+}-\mathrm{N}\right), \mathrm{C}$-to- $\mathrm{N}$ ratio of the mineralised organic matter, net $\mathrm{N}$ mineralised as percentage of total $\mathrm{N}$ and the $\Sigma \mathrm{CO}_{2}-\mathrm{C}$ as a percentage of soil organic $\mathrm{C}$ over the 30-day incubation period in abandoned terrace soils from four fallow age classes collected at the mountain oasis of Maqta, Oman. $C V_{T}$ mean $(n=4) C V$ between the terrace soils of a certain fallow age class $(n=2), C V_{R}$ mean $(n=8)$ $\mathrm{CV}$ between the replicate measurements $(n=3)$

\begin{tabular}{|c|c|c|c|c|c|}
\hline Fallow & $\Sigma \mathrm{CO}_{2}-\mathrm{C}$ & Net $\mathrm{N}$ mineralised & \multirow[t]{2}{*}{$\Sigma \mathrm{CO}_{2}-\mathrm{C} /$ net $\mathrm{N}$ mineralised } & \multirow{2}{*}{$\frac{\Sigma \mathrm{CO}_{2}-\mathrm{C}}{(\% \text { soil organic } \mathrm{C})}$} & \multirow{2}{*}{$\frac{\mathrm{Net} \mathrm{N} \text { mineralised }}{(\% \text { total } \mathrm{N})}$} \\
\hline (years) & \multicolumn{2}{|c|}{$\left(\mu \mathrm{g} \mathrm{g}^{-1}\right.$ soil 30 days $\left.^{-1}\right)$} & & & \\
\hline 1 & 180 & 9.6 & 19 & 1.4 & 0.8 \\
\hline $10-20$ & 72 & 6.6 & 11 & 0.6 & 0.6 \\
\hline $25-60$ & 26 & 1.4 & 20 & 0.4 & 0.4 \\
\hline $\mathrm{CV}_{\mathrm{T}}( \pm \%)$ & 24 & 16 & 29 & 16 & 29 \\
\hline $\mathrm{CV}_{\mathrm{R}}( \pm \%)$ & 9 & 39 & 20 & & \\
\hline
\end{tabular}

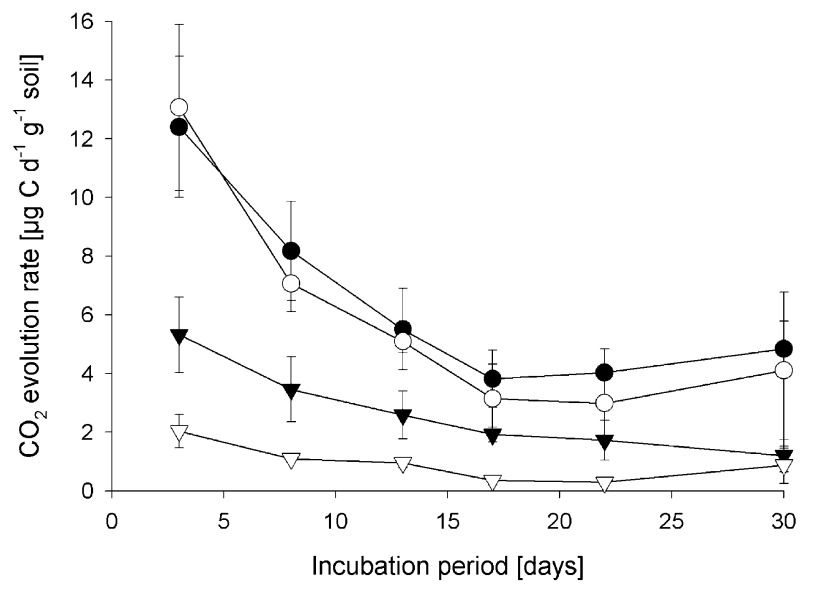

Fig. 3 Soil respiration over the 30-day incubation period in abandoned terrace soils from four fallow age classes collected at the mountain oasis of Maqta, Oman. Fallow period: 1 year $(0)$, 5 years $(\bigcirc), 10-20$ years $(\nabla), 25-60$ years $(\nabla)$. Bars indicate the $\mathrm{SD}(n=6$, two soils, triplicate measurements)

posite to the inorganic $\mathrm{N}$ fraction (Fig. $4 \mathrm{~b}$ ). At the end of the 30-day incubation period, extractable organic $\mathrm{N}$ exceeded or returned to the initial level. It should be noted that the sum of extractable organic and inorganic $\mathrm{N}$ remained roughly constant until day 23 , followed by a small increase until the end of the incubation.

The content of $0.5 \mathrm{M} \mathrm{K}_{2} \mathrm{SO}_{4}$-extractable organic $\mathrm{C}$ decreased immediately after rewetting by a third in the soils of all four fallow age classes (Fig. 4c). The fluctuations of extractable organic $\mathrm{C}$ corresponded to the respective maxima and minima of extractable organic $\mathrm{N}(r=0.69, P<0.0001, n=144)$, but were much less pronounced. However, the very high $F$-values of extractable organic $\mathrm{C}$ (Table 4) indicated that the existing differences between fallow age class, terrace soil and sampling date during the incubation experiment were at a much higher level of significance in comparison to the fraction of extractable organic $\mathrm{N}$, due to much smaller analytical error in determining extractable organic $\mathrm{C}$. Averaging the results of eight terrace soils and six sampling dates, $1.3 \%$ of total organic $\mathrm{C}$ and $1.1 \%$ of total $\mathrm{N}$ was extractable by $0.5 \mathrm{M} \mathrm{K}_{2} \mathrm{SO}_{4}$. The mean C-to- $\mathrm{N}$ ratio of the extractable fraction was 13.5 and thus slightly above the mean total-organic $\mathrm{C}$-to-total $\mathrm{N}$ ratio.

\section{Microbial biomass}

Averaging the results of eight terrace soils and six sampling dates, the content of microbial biomass $\mathrm{C}$ ranged from 65 to $296 \mu \mathrm{g} \mathrm{g}^{-1}$ soil and that of microbial biomass $\mathrm{N}$ from 10 to $39 \mu \mathrm{g} \mathrm{g}^{-1}$ soil, with a roughly constant microbial biomass C-to-N ratio of 7.0 (Table 5). The highest contents of microbial biomass were found in the soils of the 5-years fallow age class, and the lowest in those of the 25- to 60-years fallow age class. However, microbial biomass $\mathrm{C}$ revealed the strongest negative nonlinear relationship with the $\mathrm{D}$-to- $\mathrm{L}$ ratio of lysine (Fig. 1c). The microbial biomass C-to-soil organic $\mathrm{C}$ ratio ranged from $1.0 \%$ to $1.8 \%$ and declined consistently with increasing fallow age, in contrast to the microbial biomass

Table $4 \mathrm{~F}$-values of the two-way ANOVA with fallow age class and terrace soil as factors and sampling date as repeated measures for abandoned terrace soils collected at the mountain oasis of Maqta, Oman

\begin{tabular}{|c|c|c|c|c|c|c|}
\hline Age class (A) & Terrace soil $(\mathrm{T})$ & $\mathrm{A} \times \mathrm{T}$ & Sampling date $(\mathrm{S})$ & $\mathrm{S} \times \mathrm{A}$ & $\mathrm{S} \times \mathrm{T}$ & \\
\hline Microbial biomass $\mathrm{C}$ & $1,219 * * * *$ & $148 * * * *$ & $11 * * * *$ & $77 * * * *$ & $10 * * * *$ & 1 \\
\hline Microbial biomass $\mathrm{N}$ & $1,150 * * * *$ & $104 * * * *$ & 3 & $71 * * * *$ & $12 * * * *$ & $4 * *$ \\
\hline Microbial biomass C-to-N & $25 * * * *$ & $57 * * * *$ & $50 * * * *$ & $58 * * * *$ & $13 * * * *$ & $6 * * *$ \\
\hline Extractable organic $\mathrm{C}$ & $1,818 * * * *$ & $38 * * * *$ & $968 * * * *$ & $525 * * * *$ & $39 * * * *$ & 1 \\
\hline Extractable organic N & $96 * * * *$ & 1 & $42 * * * *$ & $187 * * * *$ & $25 * * * *$ & 2 \\
\hline Extractable inorganic $\mathrm{N}$ & $646 * * * *$ & $58 * * * *$ & $58 * * * *$ & $287 * * * *$ & $35 * * * *$ & $4 * *$ \\
\hline Extractable organic C-to-N & 2 & $19 * * *$ & $10 * * *$ & $8 * * * *$ & 2 & $24 * * * *$ \\
\hline$D f$ & 3 & 1 & 5 & 15 & 5 & \\
\hline
\end{tabular}

** $P<0.01, * * * P<0.001, * * * * P<0.0001$ 

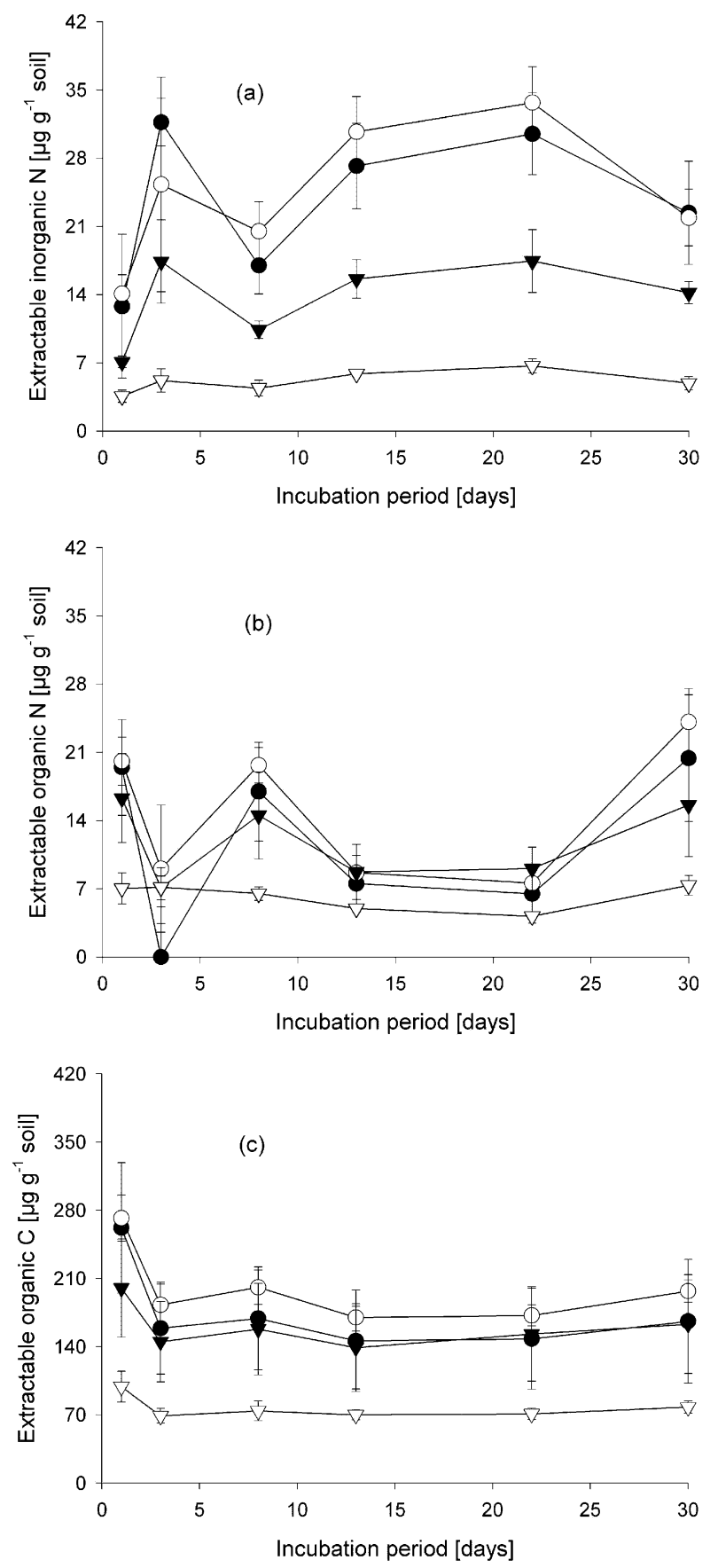

Fig. 4 a $\mathrm{K}_{2} \mathrm{SO}_{4}$-extractable inorganic $\mathrm{N}\left(\mathrm{NH}_{4}{ }^{+}-\mathrm{N}+\mathrm{NO}_{3}{ }^{-}-\mathrm{N}\right)$, b $\mathrm{K}_{2} \mathrm{SO}_{4}$-extractable organic $\mathrm{N}$, and $\mathbf{c} \mathrm{K}_{2} \mathrm{SO}_{4}$-extractable organic $\mathrm{C}$ over the 30-day incubation period in abandoned terrace soils collected from four fallow age classes at the mountain oasis of Maqta, Oman. Fallow period: 1 year $(\bigcirc), 5$ years $(\bigcirc), 10-20$ years $(\nabla), 25-60$ years $(\boldsymbol{\nabla})$. Bars indicate the SD ( $n=6$, two soils, triplicate measurements)

$\mathrm{N}$-to-total $\mathrm{N}$ ratio, which varied between 1.5 and $2.7 \%$ (Table 5).

After rewetting, the changes in microbial biomass $\mathrm{C}$ were all similar at a fallow age class-specific level during the 30-day incubation (Fig. 5). The content of microbial biomass $\mathrm{C}$ increased by $>60 \%$ within the first 3 days, followed by a decline to roughly the initial level at day 30 in all the abandoned terrace soils of the four fallow age classes. However, the temporal variations between the sampling dates were smaller than those between the paired terrace soils, and especially much smaller than those between the fallow age classes according to $F$-values (Table 4$)$.

\section{Discussion}

Effects of drying and rewetting on soil microorganisms

Dead microbial tissue and non-biomass substrate mobilised during drying (Shen et al. 1987; Appel 1998) seemed to be rapidly decomposed, promoting immediate microbial growth and causing a short-term flush of $\mathrm{CO}_{2}$ evolution similar to those observed in a silt loam sampled at the mountain oasis of Balad Seet close to the present oasis (Wichern et al., in press). However, the Maqta soils investigated here were sandy loams and the number of sampling dates after rewetting was larger and extended over a longer incubation period.

The similarity in the relative temporal changes of microbial biomass, respiration and $\mathrm{N}$ mineralisation or $\mathrm{N}$ immobilisation in the soils of the four fallow age classes is surprising considering the differences in their biological properties. The decline in the contents of microbial biomass $\mathrm{C}$ to the initial fallow age class-specific value after rewetting and incubation was another important observation. A similar finding was reported by Nannipieri et al. (1983) from an incubation experiment investigating the decomposition of glucose, leading to the hypothesis of a soil-specific biological space that maintains a certain amount of microbial biomass. The results of this study support this hypothesis without, however, explaining the exact nature of this biological space.

After rewetting, the repeated simultaneous decreases and increases in $\mathrm{K}_{2} \mathrm{SO}_{4}$-extractable fractions of organic $\mathrm{C}$, organic $\mathrm{N}$ and inorganic $\mathrm{N}$ over the 30-day incubation period indicate a succession of different microbial decomposer communities that probably differ in their ability to use recalcitrant soil organic matter. Death of a certain microbial community is reflected by increasing concentrations of extractable organic $\mathrm{C}$ and organic $\mathrm{N}$. The simultaneous decrease in inorganic $\mathrm{N}$ may be due to immobilisation by a newly growing microbial population consuming more recalcitrant $\mathrm{C}$-rich substrate. As a consequence, microbial death and growth are indicated by the opposite behaviour of extractable organic C, organic N and inorganic N. Due to simultaneous cryptic growth and death, changes of microbial communities may not always be reflected by fluctuations of microbial biomass. This clearly contradicts the statement by McGill et al. (1986) that any decrease in microbial biomass necessarily leads to a release of inorganic $\mathrm{N}$ into the soil solution. 
Table 5 Mean contents of microbial biomass $\mathrm{C}$ and microbial biomass $\mathrm{N}$, mean microbial biomass $\mathrm{C}$-to- $\mathrm{N}$ ratio, and mean ratios of microbial biomass $\mathrm{C}$-to-soil organic $\mathrm{C}$ and microbial biomass $\mathrm{N}$ to-total $\mathrm{N}$ over the six sampling dates from the 30-day incubation experiment with abandoned terrace soils from four fallow age classes collected at the mountain oasis of Maqta, Oman. $C V_{T}$ mean $(n=4) \mathrm{CV}$ between the terrace soils of a certain fallow age class $(n=2), C V_{R}$ mean $(n=48) \mathrm{CV}$ between the replicate measurements $(n=3)$

\begin{tabular}{|c|c|c|c|c|c|}
\hline Fallow & $\begin{array}{l}\text { Microbial } \\
\text { biomass C }\end{array}$ & $\begin{array}{l}\text { Microbial } \\
\text { biomass N }\end{array}$ & $\begin{array}{l}\text { Microbial } \\
\text { biomass } \mathrm{C} / \mathrm{N}\end{array}$ & $\begin{array}{l}\text { Microbial biomass } \\
\text { C/soil organic C }\end{array}$ & $\begin{array}{l}\text { Microbial biomass } \\
\text { N/total N }\end{array}$ \\
\hline (years) & $\left(\mu \mathrm{g} \mathrm{g}^{-1}\right.$ soil $)$ & & $(\%)$ & & \\
\hline 1 & 223 & 31 & 7.1 & 1.8 & 2.7 \\
\hline 5 & 296 & 39 & 7.5 & 1.7 & 2.7 \\
\hline $10-20$ & 121 & 16 & 7.3 & 1.0 & 1.5 \\
\hline $25-60$ & 65 & 10 & 6.1 & 1.0 & 2.2 \\
\hline $\mathrm{CV}_{\mathrm{T}}( \pm \%)$ & 23 & 16 & 9 & 15 & 17 \\
\hline $\mathrm{CV}_{\mathrm{R}}( \pm \%)$ & 13 & 8 & 9 & & \\
\hline
\end{tabular}

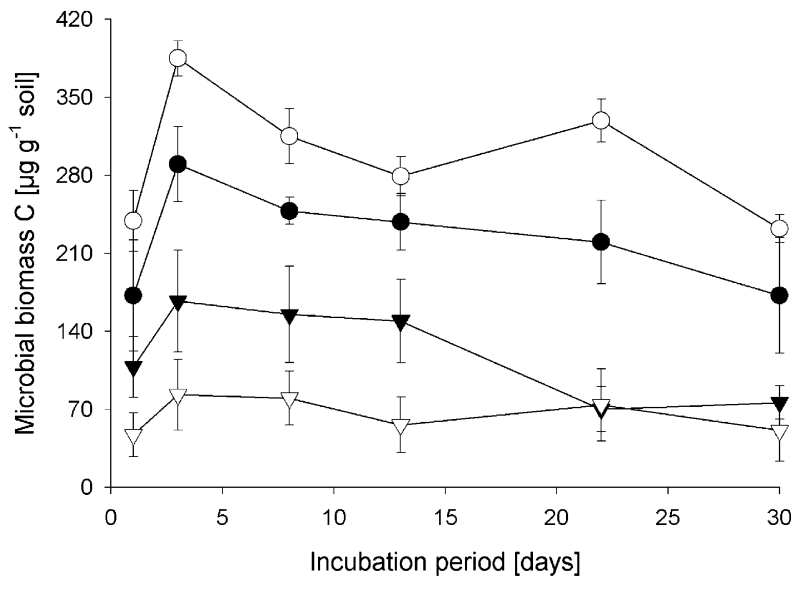

Fig. 5 Microbial biomass $\mathrm{C}$ over the 30-day incubation period in abandoned terrace soils from four fallow age classes collected at the mountain oasis of Maqta, Oman. Fallow period: 1 year $(\mathbf{)}$, 5 years $(\bigcirc), 10-20$ years $(\nabla), 25-60$ years $(\nabla)$. Bars indicate the $\mathrm{SD}$ ( $n=6$, two soils, triplicate measurements)

\section{Estimated fallow age}

The relatively low variation measured between the two terrace soils within a certain fallow age class for nearly all biological and chemical soil properties indicates that the assigning of pairs according to the recollections of the farmers was sufficiently successful, and was probably facilitated by selecting neighbouring terrace soils. However, it was difficult if not impossible to assign a terrace soil definitely to a certain year after a fallow period of $\geq 10$ years according to the recollections of the farmers interviewed. The greatest inconsistency was that the fallow of age class 10-20 years determined according to the $\mathrm{D}$ - and L -enantiomers of different amino acids (valine, leucine, and lysine) was deemed by the farmers as having lain fallow for $>50$ years. In contrast, the fallow age class of 25-60 years determined according to the $\mathrm{D}$ - and L -enantiomers was roughly consistent with the farmers' recollection that it had lain fallow for 1550 years. An unquantifiable source of error for the estimation of fallow age by the $\mathrm{D}$-to- $\mathrm{L}$ ratio of amino acids or other soil properties is wind erosion of the bare surface or the possibility of soil transfer to other terraces.

The D -to- $\mathrm{L}$ ratios of the seven amino acid enantiomers obtained from the eight terrace soils at Maqta are in the range of those given by Kimber et al. (1990) and Amelung and Zhang (2001). Assuming that all surface soils had a more or less similar D -to- L ratio prior to their abandonment, increases in the $\mathrm{D}$-to- $\mathrm{L}$ ratio with increasing fallow age are largely due to the missing input of L-amino acids, i.e. lack of rejuvenation by the input of fresh plant residues under fallow. The origin of the remaining D -enantiomers may be assigned to different sources: the peptidoglycan of bacterial cell walls (D alanine and D -glutamic acid), abiotic racemisation (e.g. lysine), microbially catalysed racemisation (e.g. aspartic acid), and formation of small amounts of $\mathrm{D}$-enantiomers during hydrolysis (e.g. proline) (Bada 1985; Amelung and Brodowski 2002; Amelung 2003). The discrimination of D -amino acids by soil microorganisms while decomposing soil organic matter may also contribute to increased D -to- L ratios to some extent (O'Dowd et al. 1997). Nevertheless, the D -to- L ratio of all amino acid enantiomers gives clear evidence for the assignment of the terrace soils to fallow age classes $>5$ years. It was difficult to differentiate significantly the 1-year and 5years fallow age classes on the basis of the D -to- L ratio, probably because the fallow period was too short. However, the increase in the D -to- L ratio for valine and leucine, although not significant during this period, gave a valid estimate of the longer fallow periods as independently proven by the increase in the $\mathrm{D}$-to- $\mathrm{L}$ ratio of lysine. The abiotic racemisation of lysine was repeatedly shown to monitor most consistently soil organic matter aging (Amelung 2003). Another possibility would be that the higher clay content in the soil of the 5-years fallow age class slows down the racemisation process. In accordance with this, Aldag (1979) observed markedly lower absorption rates of $\mathrm{D}$-amino acids on clay minerals in comparison to their $\mathrm{L}$-enantiomers leading to lower D -to- L ratios in clayey soils.

In the fallow age classes of $<10$ years, microbial activity indices seemed to be more helpful in estimating the correct order of the fallow age for the different terrace 
soils, although the D -to- L ratio of lysine revealed close non-linear relationships between microbial biomass and soil respiration in all eight abandoned terrace soils, i.e. from the early stages of the fallow period. The most stringent coherence between increasing fallow age and between the increase in fallow age and soil properties was revealed by the decreases in cumulative respiration and net $\mathrm{N}$ mineralisation rates with the decreasing availability of substrate to soil microorganisms. Microbial biomass was less suitable as an indicator of fallow age due to larger contents in the soils of the 5-years fallow age class than in those of the 1-year fallow age class. This is probably due to the protective capacity of clay for soil microorganisms, especially in sandy soils (Van Gestel et al. 1991). The microbial biomass contents in the terrace soils with a fallow age of $\leq 5$ years were similar to the values reported by Friedel et al. (2000) for irrigation agriculture in semi-arid Mexico and are in accordance with those from temperate regions (Wardle 1998). The terrace soils with a fallow age of $\geq 10$ years had microbial biomass contents similar to desert soils (Vishnevetsky and Steinberger 1997). The ability to reactivate a dormant microbial population by rewetting may decrease with increasing length of desiccation.

In conclusion, the increase in the $\mathrm{D}$-to- $\mathrm{L}$ ratios of amino acids indicates a lack of rejuvenation from a fallow period of approximately 5 years and, hence, the aging of soil organic matter. The method is therefore an important tool for assigning abandoned terrace soils to reported fallow ages in the correct order.

Under the hot arid conditions of our study area, a prolonged fallow duration appears to negatively influence soil fertility. It led to the degradation of microbial properties in the abandoned terrace soils and thus reduced the potential for later recultivation. However, one certainly has to keep in mind that water is the most limiting factor under these conditions, forcing farmers to abandon more remote fields in times of prolonged drought and decreasing water outflow of the mountain springs.

After rewetting, all microbial activity and biomass indices changed more or less similarly at a fallow age class-specific level, indicating that the same basic processes occurred in all of the sandy terrace soils investigated.

Acknowledgements The technical assistance of Gabi Dormann, Ingrid Ostermayer and Karin Schmidt is highly appreciated. We would further like to thank Eike Luedeling and Maher Nagieb for their advice and help during site location and sampling. We highly esteem the cooperation of the Sultan Qaboos University, Al Khod and of the people of Maqta. This project was partly supported by the Deutsche Forschungsgemeinschaft.

\section{References}

Aldag R (1979) Untersuchungen zur stereospezifischen Soption von D - und L -Aminosäuren am Montmorrillonit. Gött Bodenkundl Ber 58:69-131

Amelung W (2003) Nitrogen biomarkers and their fate in soil. J Plant Nutr Soil Sci 166:677-686
Amelung W, Brodowski S (2002) In vitro quantification of hydrolysis-induced racemization of amino acid enantiomers in environmental samples using deuterium labeling and electronimpact ionization mass spectrometry. Anal Chem 74:32393246

Amelung W, Zhang X (2001) Determination of amino acid enantiomers in soils. Soil Biol Biochem 33:553-562

Appel T (1998) Non-biomass soil organic N-the substrate for $\mathrm{N}$ mineralization flushes following soil drying-rewetting and for organic $\mathrm{N}$ rendered $\mathrm{CaCl}_{2}$-extractable upon soil drying. Soil Biol Biochem 30:1445-1456

Bada JL (1985) Racemization of amino acids. In: Barrett GC (ed) Chemistry and biochemistry of amino acids. Chapman and Hall, London, pp 399-414

Brookes PC, Landman A, Pruden G, Jenkinson DS (1985) Chloroform fumigation and the release of soil nitrogen: a rapid direct extraction method for measuring microbial biomass nitrogen in soil. Soil Biol Biochem 17:837-842

Craswell ET, Lefroy RDB (2001) The role and function of organic matter in tropical soils. Nutr Cycl Agroecosyst 61:7-18

Dilly O (2001) Microbial respiratory quotient during basal metabolism and after glucose amendment in soils and litter. Soil Biol Biochem 33:117-127

Fierer N, Schimel JP (2002) Effects of drying-rewetting frequency on soil carbon and nitrogen transformations. Soil Biol Biochem 34:777-787

Friedel JK, Langer T, Siebe C, Stahr K (2000) Effects of long-term waste water irrigation on soil organic matter, soil microbial biomass and its activities in central Mexico. Biol Fertil Soils 31:414-421

Gee GW, Bauder JW (1986) Particle-size analysis. In: Methods of soil analysis. Part I. Physical and mineralogical methods, 2nd edn. (Agronomy Monograph no. 9.) pp 83-411

Joergensen RG, Mueller T (1996) The fumigation-extraction method to estimate soil microbial biomass: calibration of the $k_{\mathrm{EN}}$ value. Soil Biol Biochem 28:33-37

Kimber RWL, Nannipieri P, Ceccanti B (1990) The degree of racemization of amino acids released by hydrolysis of humicprotein complexes: implications for age assessment. Soil Biol Biochem 22:181-185

Kimber RWL, Kennedy, NM, Milnes, AR (1994) Amino acid racemization dating of a 140,000-year-old tephra-loess-palaeosol sequence on the Mamaku Plateau near Rotorua, New Zealand. Aust J Earth Sci 41:19-26

Kvenvolden K, Peterson E (1970) Racemization of amino acids in sediments from Saanich inlet, British Columbia. Science 169:1079-1082

Mahaney WC, Rutter NW (1989) Amino acid D/L ratio distributions in two late quaternary soils in the afroalpine zone of Mount Kenya, East Africa. Catena 16:205-214

Mainguet M (1998) Aridity: droughts and human development. Springer, Berlin Heidelberg New York

McGill WB, Cannon KR, Robertson JA, Cook FD (1986) Dynamics of soil microbial biomass and water soluble organic $\mathrm{C}$ in Breton L after 50 years of cropping two rotations. Can J Soil Sci 66:1-19

Miller GH, Magee JW, Jull AJT (1997) Low-latitude glacial cooling of the southern hemisphere from amino acid racemization in emu eggshells. Nature 385:241-244

Nagata Y, Fujiwara, T, Kawaguchi-Nagata K, Fukumori Y, Yamanaka T (1998) Occurrence of peptidyl- D -amino acids in soluble fractions of several eubacteria, archaea and eukayotes. Biochim Biophys Acta 1379:76-82

Nagieb M, Häser J, Siebert S, Luedeling E, Buerkert A (2004) Settlement history of a mountain oasis in Northern Oman Agriculture-Evidence from land use and archaeological studies. Erde (in press)

Nannipieri P, Muccini L, Ciandi C (1983) Microbial biomass and enzyme activities: production and persistence. Soil Biol Biochem 15:679-685 
Norman WR, Shayya WH, Al-Ghafri AS, Mc Cann IR (1998) Aflaj irrigation and on-farm water management in northern Oman. Irrig Drain Syst 12:35-48

O'Dowd RW, Parsons R, Hopkins DW (1997) Soil respiration induced by the $\mathrm{D}$ - and $\mathrm{L}$-isomers of a range of amnio acids. Soil Biol Biochem 29:1665-1671

Robertz M, Muckenheim T, Eckl S, Webb L (1999) Kostengünstige Labormethode zur Bestimmung der mikrobiellen Bodenatmung nach DIN 19737. Wasser Boden 51(5):48-53

Schlichting E, Blume HP, Stahr K (1995) Bodenkundliches Praktikum, 2nd edn. Blackwell, Berlin

Shen SM, Brookes PC, Jenkinson DS (1987) Soil respiration and measurement of microbial biomass $\mathrm{C}$ by the fumigation technique in fresh and in air-dried soil. Soil Biol Biochem 19:153-158

Van Gestel M, Ladd JN, Amato M (1991) Carbon and nitrogen mineralization from two soils of contrasting texture and microaggregate stability: influence of sequential fumigation, drying and storage. Soil Biol Biochem 23:313-322

Vance ED, Brookes PC, Jenkinson DS (1987) An extraction method for measuring soil microbial biomass C. Soil Biol Biochem 19:703-707
Vishnevetsky S, Steinberger Y (1997) Bacterial and fungal dynamics and their contribution to microbial biomass in desert soil. J Arid Environ 37:83-90

Wardle DA (1998) Controls of temporal variability of the soil microbial biomass: a global scale synthesis. Soil Biol Biochem 30:1627-1637

West AW, Sparling GP, Speir TW (1989) Microbial activity in gradually dried or rewetted soils as governed by water and substrate availability. Aust J Soil Res 27:747-757

Wichern F, Luedeling E, Müller T, Joergensen RG, Buerkert A (2004a) Field measurements of the $\mathrm{CO}_{2}$ evolution rate under different crops during an irrigation cycle in a mountain oasis of Oman. Appl Soil Ecol 25:85-91

Wichern F, Müller T, Joergensen RG, Buerkert A (2004b) Effects of manure quality and application forms on soil $\mathrm{C}$ and $\mathrm{N}$ turnover of a subtropical oasis soil under laboratory conditions. Biol Fertil Soils 39:165-171

Wu J, Joergensen RG, Pommerening B, Chaussod R, Brookes PC (1990) Measurement of soil microbial biomass-C by fumigation-extraction - an automated procedure. Soil Biol Biochem 22:1167-1169 